\title{
Evaluation of Biofloc Technology for Astacus leptodactylus: Effect of Different Stocking Densities on Production Performance and Physiological Responses
}

\section{Doğukan KAYA ${ }^{1 *} \oplus$, Ercument GENÇ ${ }^{2} \oplus$, Derya GÜROY ${ }^{3} \oplus$, Serhat DİNÇER ${ }^{2} \oplus$, Bilgenur HARMANŞA YILMAZ ${ }^{2}$, Hijran YAVUZCAN YILDIZ ${ }^{2}$}

\author{
${ }^{1}$ Tokat Gaziosmanpasa University, Agricultural Applications, and Research Center, Tokat, Turkey \\ ${ }^{2}$ Ankara University, Faculty of Agriculture, Department of Fisheries and Aquaculture Engineering, 06110 \\ Dıșkapı, Ankara, Turkey \\ ${ }^{3}$ Yalova University, Department of Aquaculture, Armutlu Vocational College, Yalova, Turkey \\ *Corresponding author: aquadogukankaya@gmail.com
}

Received 20 April 2021; Accepted 14 July 2021; Release date 01 December 2021.

How to Cite: Kaya, D., Genç, E., Güroy, D., Dinçer, S., Harmanşa Yılmaz, B., \& Yavuzcan Yıldız, H. (2021). Evaluation of biofloc technology for Astacus leptodactylus: Effect of different stocking densities on production performance and physiological responses. Acta Aquatica Turcica, 17(4), 569-579. https://doi.org/10.22392/actaquatr.920606

\begin{abstract}
The use of biofloc technology (BFT) in narrow-clawed crayfish (Astacus leptodactylus) culture for 45 days was evaluated by production performance and physiological status of crayfish. Four different stocking densities of crayfish were tested in BFT $\left(20,41.66,62.5\right.$, and 83.33 individuals $\left.\mathrm{m}^{-2}\right)$. Water quality parameters were monitored to sustain desired levels for crayfish and biofloc management. The growth performance of narrow-clawed crayfish did not show any significant differences among the groups. However, the survival rate changed by the stocking density. Hemolymph indices represented by total hemocyte counts and relative abundance of hyalinocyte, semi-granulocyte, and granulocyte were not affected by different stocking densities. Overall hemolymph glucose and lactate levels of narrow-clawed crayfish reflected mild stress in response to BFT conditions. Hemolymph protein concentrations did not change by the stocking ratio in BFT. Hemolymph protein levels were in the normal range, indicating the healthy status of the individuals. The hepatopancreas histology was observed as a typical morphology for healthy crayfish in all stocking densities in BFT. Notwithstanding the relatively lower survival rate in higher stocking density of narrow-clawed crayfish, the results of the present research revealed that the adaptation of narrow-clawed crayfish to BFT conditions is promising for the crayfish culture.
\end{abstract}

Keywords: Biofloc, Astacus leptodactylus, stocking density, growth, physiological response

Astacus leptodactylus İçin Biyoyumak Teknolojisinin Değerlendirilmesi: Farklı Stoklama Yoğunluklarının Üretim Performansı ve Fizyolojik Tepkileri Üzerine Etkisi

Özet

Biyoyumak teknolojisinin (BFT) Astacus leptodactylus yetiştiriciliğinde üretim performansı ve fizyolojik durumuna etkileri 45 gün süreyle değerlendirilmiştir. Kerevitler dört farklı stoklama yoğunluğunda $\left(20,41.66,62.5\right.$ ve 83.33 adet $\left.\mathrm{m}^{-2}\right)$ BFT ortamında test edilmiştir. Su kalitesi parametreleri kerevit ve biyoyumak ortamı için istenen seviyeleri sürdürmek amacıyla takip edilmiştir. Çalışmanın sonunda kerevitlerin büyüme performansı gruplar arasında önemli bir farklılık göstermemiştir. Bununla birlikte, farklı stoklama yoğunluklarının yaşama oranlarını etkilediği belirlenmiştir $(p<0.05)$. Toplam hemosit sayıları ve göreceli olarak hyalinosit, yarı granülosit ve granülosit bolluğu ile temsil edilen hemolenf indeksleri, farklı stoklama yoğunluklarından etkilenmemiştir. Ancak kerevitin genel hemolenf glikoz ve laktat seviyeleri, BFT koşullarına yanıt olarak hafif stresi yansıtmıştır. Hemolenf protein konsantrasyonları, BFT'deki stoklama yoğunluğuna göre değişmemiştir. Hemolimf protein seviyeleri ise kerevitlerin sağlıklı durumunu gösteren normal sınırlar arasında bulunmuştur. Hepatopankreas histolojisi, BFT'deki tüm stoklama yoğunluğunda sağlıklı kerevit için tipik bir yapı göstermiştir. Kerevitlerin daha yüksek stoklama yoğunluğundaki nispeten düşük yaşama oranına rağmen, mevcut araştırmanın sonuçları, kerevitlerin BFT koşullarına adaptasyonunun kerevit yetiştiriciliği için umut verici olduğunu ortaya koymuştur.

Anahtar Kelimeler: Biyoyumak, Astacus leptodactylus, stoklama yoğunluğu, büyüme, fizyolojik yanıt

\section{INTRODUCTION}

Decapod crustaceans are represented by the second-highest market value among the world's aquaculture production (FAO, 2018). Narrow-clawed crayfish (Astacus leptodactylus) as a decapod is 
also considered a species that has consumer demands (Farhadi and Jensen, 2016; Harlioglu and Farhadi, 2017). This species is widely distributed in Europe, East Russia, and the Middle East and mostly cultured in extensive and semi-intensive farms. However, intensive culture possibilities are limited due to the absence of suitable commercial feed and the disease as well as cannibalism problems (Nedaei et al., 2019). Moreover, late sexual maturity age, the long incubation period of the eggs, slow growth rates, and disease problems are common disadvantages for the intensive culture of narrow-clawed crayfish.

Stocking density is one of the most important factors affecting yield in decapod culture. Crustaceans naturally exhibit territorial and aggressive behavior, increasing the food competition at high stocking densities in culture systems. Therefore, determining the appropriate stocking density specific to the species is also an indicator of culture performance (Yu et al., 2020).

Many culture techniques and feed formulations can be used to minimize disease outbreaks and ensure the sustainability of production (Safari and Paolucci, 2017). Apart from traditional culture applications, new practical methods such as BFT that improve the culture performance, health status, and water quality parameters have been developed in recent years (Minaz and Kubilay, 2021). BFT has many positive effects on the survival rate, growth, and immune system and also reduction in cannibalism even at high stocking densities for cultured decapods (Fóes et al., 2011; Liu et al., 2017; Negrini et al., 2017; Kaya et al., 2020).

In Decapoda, hemo-cytological analysis can provide an insight into the physiological and immunological status of the individuals (Gargioni and Barracco, 1998; Lin and Söderhäll, 2011; Hauton, 2012; Kaya et al., 2019b). Hemocytes are the cells found in the hemolymph that is in the center of the protective system of the crayfish as in other crustaceans. Hemocytes are involved in nonspecific immune systems associated with non-self-recognition and alterations in hemocyte count may indicate the crayfish's health directly (Söderhall et al., 1988). Hemolymph indices, representing total hemocyte counts and relative abundance of the hyalinocytes, semi-granulocytes, and granulocytes are a valuable tool to assess the health of crayfish. The circulating hemocytes can be affected by many factors such as water quality, food intake, starvation, environmental conditions, grow-out methods, life cycle, molting, diseases, etc (Winzer, 2005). Thus, BFT as a culture technique can influence the nonspecific immune system associated with hemolymph indices (Panigrahi et al., 2019b). Hemolymph metabolites such as protein, lactate, and glucose levels in the hemolymph of the crayfish are the biomarkers to detect the physiological status of crayfish (Bonvillain et al., 2012). Increases in hemolymph glucose level, under the effect of crustacean hyperglycemic hormone, has been reported to be a secondary stress response (Jussila et al., 1998). Thus, hemolymph glucose and lactate have been classified under the acute stress biomarkers in crayfish (Bonvillain et al., 2012). Hemolymph protein is another biomarker that can be used in the evaluation of health status and particularly for the linkage between food intake and the condition of the crayfish (Sladkova and Kholodkevich, 2011). The hepatopancreas is the main organ for digestion metabolism. Due to these characteristics, hepatopancreas tissue and cell types have been intensively investigated (Vogt, 2019). The organ is responsible for nutrient absorption, lipid storage, and digestive enzyme synthesis (Johnson, 1980; Genc et al., 2007). Therefore, the monitoring of hepatopancreas can be a useful indicator of decapod metabolism.

The negative effects of increased stocking rates on narrow-clawed crayfish have been reported by many researchers (Ulikowski and Krzywosz, 2004; Mazlum, 2007; Farhadi and Jensen, 2016), but there is no study related to evaluation stocking densities with BFT in narrow-clawed crayfish. In our previous study (Genc et al., 2019), narrow-clawed crayfish with an initial weight of 37,61g showed a $100 \%$ survival rate in BFT compared to the clear water conditions $(77.77 \%)$ in stocking density of 28.57 crayfish $\mathrm{m}^{-2}$. This result demonstrated that BFT could be directly implemented in practice for the narrow-clawed crayfish culture instead of a clear water technique. For this reason, this study aimed to evaluate the effects of higher stocking densities on survival, growth performance, body composition, and physiological response of narrow-clawed crayfish in BFT conditions.

\section{MATERIAL and METHODS Ethical Statement}

The authors declare that this study complies with the ethical policies that the scientific journal has been adhered to. In this study, a crayfish (Decapoda) was used as an experimental animal. Regarding 
"the Scientific Purposes Used Animal Protection to the European Union Directive" (2010/63/EU dated), and the "Republic of Turkey the Experimental and other Scientific Purposes of Animals used for a Regulation on the Welfare and Conservation" (13.12.2011 date, 28141 number); the crayfish as an invertebrate organism the permission is not subjected.

\section{Experimental Design, Water, and Growth Parameters}

The experiment was carried out in recirculating aquaculture system (RAS) for 45 days at Fisheries Research and Application Unit (Faculty of Agriculture, Ankara University), Each tank of the RAS had a bottom area of $0.24 \mathrm{~m}^{-2}$ and with a volume of $40 \pm 0.5 \mathrm{~L}$. Narrow-clawed crayfish at the intermolt stage were obtained from the stock in the Unit. One hundred and fifty crayfish were randomly distributed to each RAS tank in stocking densities of 5, 10, 15, and 20 individuals corresponding to 20.83 (Group S1), 41.66 (Group S2), 62.5 (Group S3), and 83.33 (Group S4) individuals $\mathrm{m}^{-2}$, respectively. Each group was tested with three replicates. During the trial, $12 \mathrm{~h}$ of light and $12 \mathrm{~h}$ of dark conditions were maintained. In the experiment, feed containing $38.1 \%$ protein and $9.1 \%$ fat was used (Table 1). Feeding was started at a rate of $4.5 \%$ body weight (BW) day ${ }^{-1}$ and adjusted by reducing $1.5 \%$ every 15 days.

For biofloc production, sugar beet molasses (Beta vulgaris) (Ankara Sugar Company, Turkey) was added after daily feeding in a $\mathrm{C}$ : $\mathrm{N}$ ratio of 15:1 according to Avnimelech (2012). During the experiment, the addition of molasses for the daily feeding rate was adjusted by the report of Kaya et al. (2020). The biofloc volume was measured daily for ensuring an ideal level $\left(10-20 \mathrm{ml} \mathrm{L}^{-1}\right)$ using the Imhoff cone (Avnimelech, 2012).

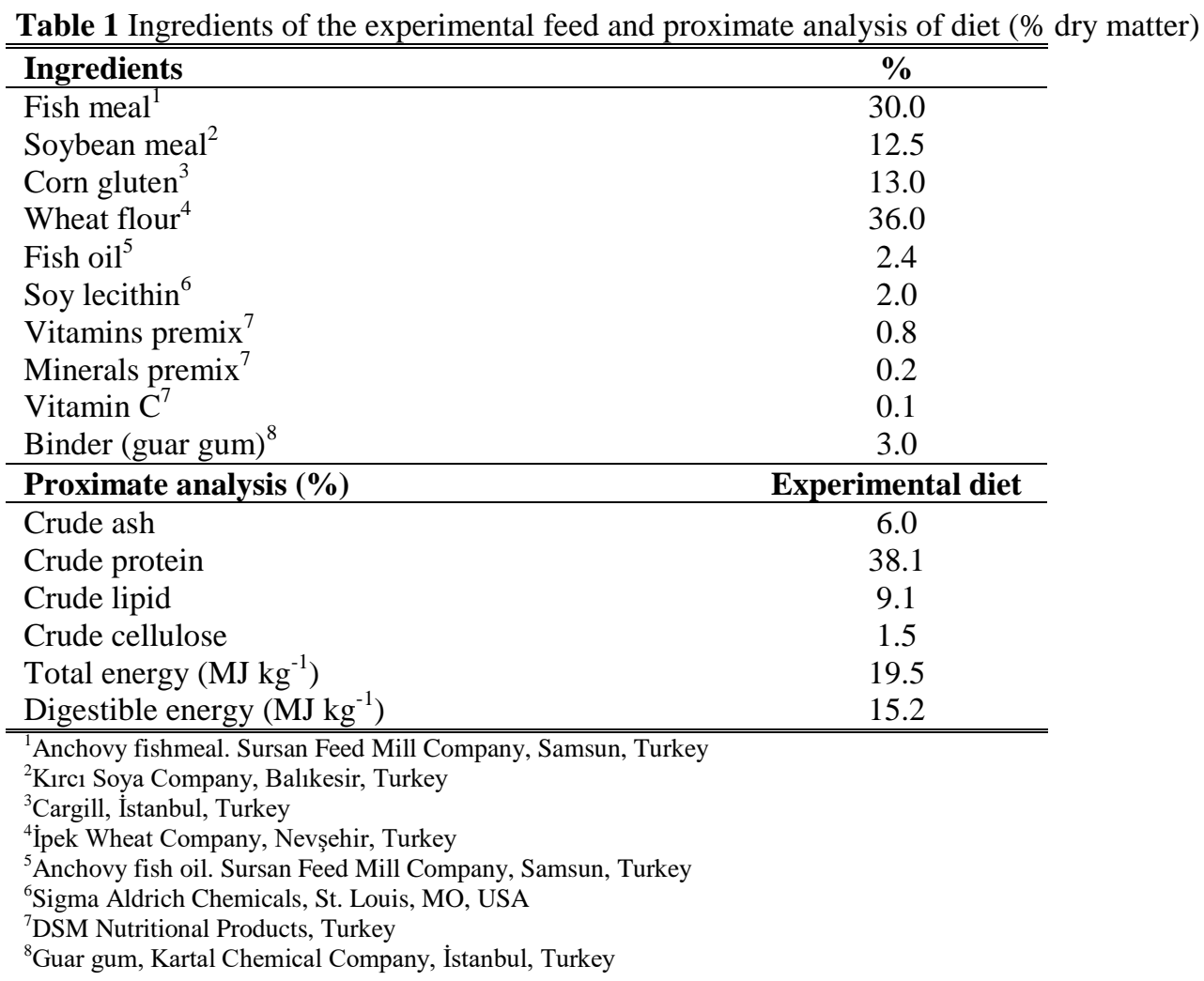

The weight gain, specific growth rate, feed conversation ratio, survival rate, and the moult frequency (percentage of moulted crayfish) in each stocking group were calculated using the following equations:

Weight gain $(\mathrm{WG})=\mathrm{W}_{\text {final }}(\mathrm{g})-\mathrm{W}_{\text {initial }}(\mathrm{g}) / \mathrm{W}_{\text {initial }}(\mathrm{g}) \times 100$

Specific growth rate $(\mathrm{SGR})=100\left(\ln \mathrm{W}_{\text {final }}-\ln \mathrm{W}_{\text {initial }}\right) /$ Time

Feed conversation ratio $(\mathrm{FCR})=$ feed intake $(\mathrm{g}) /$ weight gain $(\mathrm{g})$

Survival rate $(\mathrm{SR})=\left(\mathrm{N}_{\text {final }} / \mathrm{N}_{\text {initial }}\right) \times 100$

Moulting Frequency $(\mathrm{MF}) \%=\left(\mathrm{N}_{\mathrm{mo}} / \mathrm{N}_{\mathrm{s}}\right) \times 100\left(\mathrm{~N}_{\mathrm{mo}}=\right.$ the total number of moulted crayfish per group during the experiment, $\mathrm{N}_{\mathrm{s}}=$ the total number of live crayfish per group). 
The proximate compositions of the narrow-clawed crayfish were determined based on the Association of Analytical Communities (AOAC, 1997), the Kjeldahl method was used for the crude protein $(\mathrm{N} \times 6.25)$ and the crude ash was determined by combustion in a muffle furnace at $550{ }^{\circ} \mathrm{C}$ for $16 \mathrm{~h}$. The total lipid concentration was carried out according to the method described by Bligh and Dyer (1959).

\section{Water Parameters}

Water temperature, dissolved oxygen, saturation, and salinity levels were recorded daily using a multi-parameter instrument (YSI ${ }^{\circledR}$ 556, YSI Inc., Yellow Springs, OH, USA). Nitrite, nitrate, and phosphate measurements were performed every week (APHA, 1998). Daily measured water quality parameters and nitrite, nitrate, and phosphate values of the BFT system are shown in Table 2.

\begin{tabular}{lll}
\multicolumn{3}{c}{ Table 2 Water parameters of the RAS system } \\
\hline \hline Parameter & BFT & N \\
\hline $\mathrm{T}\left({ }^{\circ} \mathrm{C}\right)$ & $22.7 \pm 0.9$ & 45 \\
DO $\left(\mathrm{mg} \mathrm{L}^{-1}\right)$ & $6.5 \pm 0.4$ & 45 \\
Saturation (\%) & $75 \pm 5.0$ & 45 \\
$\mathrm{pH}$ & $7.8 \pm 0.4$ & 45 \\
Salinity (ppt) & 0.002 & 45 \\
$\mathrm{~N}^{-\mathrm{NO}_{2}}{ }^{-}\left(\mathrm{mg} \mathrm{L}^{-1}\right)$ & $0.2 \pm 0.1$ & 6 \\
$\mathrm{~N}^{-N^{-1}}{ }_{3}^{-}\left(\mathrm{mg} \mathrm{L}^{-1}\right)$ & $2.1 \pm 0.3$ & 6 \\
$\mathrm{PO}_{4}\left(\mathrm{mg} \mathrm{L}^{-1}\right)$ & $0.4 \pm 0.2$ & 6 \\
$\mathrm{Biofloc}^{-1}$ volume $\left(\mathrm{ml} \mathrm{L}^{-1}\right)$ & $14.2 \pm 4.5$ & 45 \\
\hline \hline N: sampling number & &
\end{tabular}

\section{Hemolymph Sampling and Analysis \\ Hemolymph Indices}

Total hemocyte counts and relative abundance of hemocyte types (hyalinocytes, semi-granulocytes, and granulocytes) were determined to form hemolymph indices. Hemolymph sampling was carried out at the end of the experiment. Hemolymph samples from each crayfish were withdrawn by the pericardial cavity puncture with a hypodermic needle and transferred to Eppendorf tubes to dilute with crustacean anticoagulant (1:2) for total and differential hemocyte counts. Collected hemolymph was pooled to enable enough amount for the analysis. Crustacean anticoagulant was the solution of citrate buffer and EDTA (Anderson et al., 1997). Total and differential hemocyte counts (THCs) were established by the hemolymph in crustacean anticoagulants using a Neubauer hemocytometer (Persson et al., 1987). In determining the differential hemocyte counts, hemolymph in the anticoagulant mixture was dropped on a slide and smeared. In brief, air-dried smears were fixed in $70 \%$ methanol and then stained with May-Grunwald and Giemsa (Bancroft and Stevens, 1977). Approximately 100 cells were counted under a microscope to differentiate the hemocyte types (hyaline cells, semi-granulocytes, and granulocytes).

\section{Hemolymph Metabolites}

Hemolymph protein, glucose, and lactate were analyzed in hemolymph samples without anticoagulants. Hemolymph samples were allowed to clot and stored at $4{ }^{\circ} \mathrm{C}$. Before analysis thawed samples were centrifuged and the supernatant was collected. Commercial kits (Cayman Chemicals, USA) were used for hemolymph metabolites: hemolymph protein, glucose, and lactate determination. In hemolymph metabolites, the instructions of the manufacturer were followed.

\section{Statistical Analysis}

In the statistical analysis of the data obtained the package program (SPSS 17.0, Chicago, IL, USA) was used. One-way ANOVA and Duncan multiple range tests were used for comparing different stocking densities among the BFT groups (mean \pm standard deviation). The statistical significance of the data was considered as $p<0.05$. 


\section{RESULTS}

S1 group clearly showed better growth performance among the groups $(p<0.05)$ (Table 3$)$. Increased stocking densities negatively affected the final weight values of crayfish. Moreover, the feed conversion ratio changed by the groups, and the best feed conversion ratio was obtained from the S1 group $(p<0.05)$. The survival rate was the highest in the group with a minimum stocking density (S1). Moulting frequency was not statistically affected by increased stocking rates for all groups $(p>0.05)$. Lipid content of tail meat did not differ among the experimental groups, however, protein amount in tail meat increased significantly in comparison to initial values of tail meat of narrow-clawed crayfish (Table 4). Moisture and ash amount of tail meat decreased in biofloc groups in comparison to initial values $(p>0.05)$.

Hemolymph indices representing the total hemocyte counts (THCs) and relative abundance of hemocyte types (hyalinocyte, semi-granulocyte, and granulocyte) did not differ among the groups $(p>0.05)$ (Table 5). From the hemolymph metabolites measured, hemolymph protein and lactate did not change by the stocking density of crayfish $(p>0.05)$. Hemolymph glucose increased in the group of $\mathrm{S} 2$ and $\mathrm{S} 3$ in comparison to group S1 and S4 ( $p>0.05$ ) (Table 6).

The hepatopancreas sections indicated normal tissue architecture. Examined hepatopancreas tissue was not adversely affected by different stocking applications (Figure 1). Normal histomorphology has been observed in hepatopancreatic tubular cells and central lumens in the narrow-clawed crayfish of all groups. There were no pathological changes in the hepatopancreas of the examined crayfish during the experiment.

Table 3 Growth performance of crayfish, A. leptodactylus in different stocking densities with BFT

\begin{tabular}{lcccc}
\hline \hline & S1 & S2 & S3 & S4 \\
\hline IW g & $7.27 \pm 0.06^{\mathrm{a}}$ & $7.28 \pm 0.09^{\mathrm{a}}$ & $7.28 \pm 0.07^{\mathrm{a}}$ & $7.28 \pm 0.07^{\mathrm{a}}$ \\
FW g & $13.86 \pm 1.00^{\mathrm{b}}$ & $12.25 \pm 1.88^{\mathrm{a}}$ & $11.75 \pm 1.83^{\mathrm{a}}$ & $12.12 \pm 2.02^{\mathrm{a}}$ \\
WG g & $6.59 \pm 0.99^{\mathrm{b}}$ & $4.97 \pm 1.89^{\mathrm{a}}$ & $4.84 \pm 2.01^{\mathrm{a}}$ & $4.47 \pm 1.82^{\mathrm{a}}$ \\
DWG g & $0.07 \pm 0.01^{\mathrm{b}}$ & $0.05 \pm 0.02^{\mathrm{a}}$ & $0.05 \pm 0.02^{\mathrm{a}}$ & $0.05 \pm 0.02^{\mathrm{a}}$ \\
SGR\% day ${ }^{-1}$ & $0.70 \pm 0.08^{\mathrm{b}}$ & $0.55 \pm 0.18^{\mathrm{a}}$ & $0.54 \pm 0.19^{\mathrm{a}}$ & $0.51 \pm 0.16^{\mathrm{a}}$ \\
FCR & $1.94 \pm 0.07^{\mathrm{a}}$ & $2.60 \pm 0.36^{\mathrm{ab}}$ & $2.71 \pm 0.54^{\mathrm{ab}}$ & $2.90 \pm 0.47^{\mathrm{b}}$ \\
MF \% & $80.00 \pm 17.64^{\mathrm{a}}$ & $60.86 \pm 6.49^{\mathrm{a}}$ & $59.00 \pm 18.56^{\mathrm{a}}$ & $57.72 \pm 16.24^{\mathrm{a}}$ \\
SR \% & $100.00 \pm 0.00^{\mathrm{b}}$ & $93.33 \pm 5.77^{\mathrm{ab}}$ & $91.11 \pm 3.85^{\mathrm{a}}$ & $88.33 \pm 2.89^{\mathrm{a}}$ \\
\hline \hline
\end{tabular}

S1: 5 crayfish $0.24 \mathrm{~m}^{-2}$. S2: 10 crayfish $0.24 \mathrm{~m}^{-2}$. S3: 15 crayfish $0.24 \mathrm{~m}^{-2}$. S4: 20 crayfish $0.24 \mathrm{~m}^{-2}$

IW: initial weight, FW: final weight, WG: weight gain, DWG: daily weight gain, SGR: specific growth rate $\left(\% \mathrm{day}^{-1}\right)$, FCR: feed conversion ratio, MF: moulting frequency (\%), SR: survival rate (\%).

Table 4 Proximate composition of tail meat (wet-weight basis) of narrow-clawed crayfish in different stocking densities

\begin{tabular}{cccccc}
\hline \hline & Initial & S1 & S2 & S3 & S4 \\
\hline Moisture (\%) & $81.17 \pm 0.40^{\mathrm{b}}$ & $79.07 \pm 0.57^{\mathrm{a}}$ & $79.33 \pm 0.91^{\mathrm{ab}}$ & $79.87 \pm 1.65^{\mathrm{ab}}$ & $79.17 \pm 1.01^{\mathrm{a}}$ \\
Protein (\%) & $16.63 \pm 1.25^{\mathrm{a}}$ & $18.28 \pm 0.42^{\mathrm{b}}$ & $18.20 \pm 0.54^{\mathrm{b}}$ & $18.02 \pm 0.89^{\mathrm{ab}}$ & $18.22 \pm 0.61^{\mathrm{b}}$ \\
Lipid (\%) & $0.80 \pm 0.10^{\mathrm{a}}$ & $1.07 \pm 0.15^{\mathrm{a}}$ & $1.03 \pm 0.42^{\mathrm{a}}$ & $0.93 \pm 0.15^{\mathrm{a}}$ & $1.17 \pm 0.31^{\mathrm{a}}$ \\
Ash (\%) & $1.23 \pm 0.06^{\mathrm{b}}$ & $1.16 \pm 0.03^{\mathrm{ab}}$ & $1.19 \pm 0.05^{\mathrm{ab}}$ & $1.14 \pm 0.05^{\mathrm{a}}$ & $1.20 \pm 0.02^{\mathrm{ab}}$ \\
\hline \hline S1: 5 crayfish $0.24 \mathrm{~m}^{-2}$. S2: 10 crayfish $0.24 \mathrm{~m}^{-2}$. S3: 15 crayfish $0.24 \mathrm{~m}^{-2} . \mathrm{S} 4: 20{\text { crayfish } 0.24 \mathrm{~m}^{-2}}$
\end{tabular}


Table 5 Hemolymph indices of narrow-clawed crayfish, A. leptodactylus in different stocking densities

\begin{tabular}{lcccc}
\hline Stocking density groups & S1 & S2 & S3 & S4 \\
\hline $\begin{array}{l}\text { Total hemocyte counts } \\
\left(\times 10^{4} \text { cells mL }\right)^{-1}\end{array}$ & $52.58 \pm 15.88^{\mathrm{ab}}$ & $51.19 \pm 14.85^{\mathrm{ab}}$ & $49.70 \pm 17.71^{\mathrm{a}}$ & $47.93 \pm 15.49^{\mathrm{a}}$ \\
\hline $\begin{array}{l}\text { The relative abundance } \\
\text { of hemocyte types }\end{array}$ & & & & \\
\hline Semigranulocyte $(\%)$ & $14.26 \pm 9.10^{\mathrm{ab}}$ & $14.54 \pm 9.47^{\mathrm{ab}}$ & $12.95 \pm 8.08^{\mathrm{a}}$ & $12.45 \pm 9.32^{\mathrm{a}}$ \\
Granulocyte (\%) & $19.15 \pm 12.37^{\mathrm{a}}$ & $19.70 \pm 11.63^{\mathrm{a}}$ & $20.60 \pm 10.25^{\mathrm{a}}$ & $20.52 \pm 11.54^{\mathrm{a}}$ \\
Hyalinocyte (\%) & $66.59 \pm 14.28^{\mathrm{a}}$ & $65.76 \pm 17.08^{\mathrm{a}}$ & $66.45 \pm 12.38^{\mathrm{a}}$ & $67.03 \pm 16.84^{\mathrm{a}}$ \\
\hline \hline
\end{tabular}

S1: 5 crayfish $0.24 \mathrm{~m}^{-2}$. S2: 10 crayfish $0.24 \mathrm{~m}^{-2}$. S3: 15 crayfish $0.24 \mathrm{~m}^{-2}$. S4: 20 crayfish $0.24 \mathrm{~m}^{-2}$

Table 6 Hemolymph metabolites of narrow-clawed crayfish, A. leptodactylus in different stocking densities

\begin{tabular}{lllll}
\hline \hline Stocking density groups & S1 & S2 & S3 & S4 \\
\hline Hemolymph protein $\left(\mathrm{mg} \mathrm{mL}^{-1}\right)$ & $2.94 \pm 0.08^{\mathrm{a}}$ & $2.82 \pm 0.05^{\mathrm{a}}$ & $2.48 \pm 0.18^{\mathrm{a}}$ & $2.71 \pm 0.12^{\mathrm{a}}$ \\
Hemolymph lactate $\left(\mathrm{mg} \mathrm{dL}^{-1}\right)$ & $60.16 \pm 1.47^{\mathrm{a}}$ & $61.32 \pm 1.41^{\mathrm{a}}$ & $63.83 \pm 0.98^{\mathrm{ab}}$ & $61.16 \pm 3.54^{\mathrm{a}}$ \\
Hemolymph glucose $\left(\mathrm{mg} \mathrm{dL}^{-1}\right)$ & $54.86 \pm 0.76^{\mathrm{a}}$ & $60.96 \pm 0.71^{\mathrm{ab}}$ & $60.72 \pm 0.89^{\mathrm{ab}}$ & $55.16 \pm 1.16^{\mathrm{a}}$ \\
\hline S1: 5 crayfish $0.24 \mathrm{~m}^{-2}$. S2: 10 crayfish $0.24 \mathrm{~m}^{-2}$. S3: 15 crayfish $0.24 \mathrm{~m}^{-2} . \mathrm{S} 4: 20$ crayfish $0.24 \mathrm{~m}^{-2}$ &
\end{tabular}
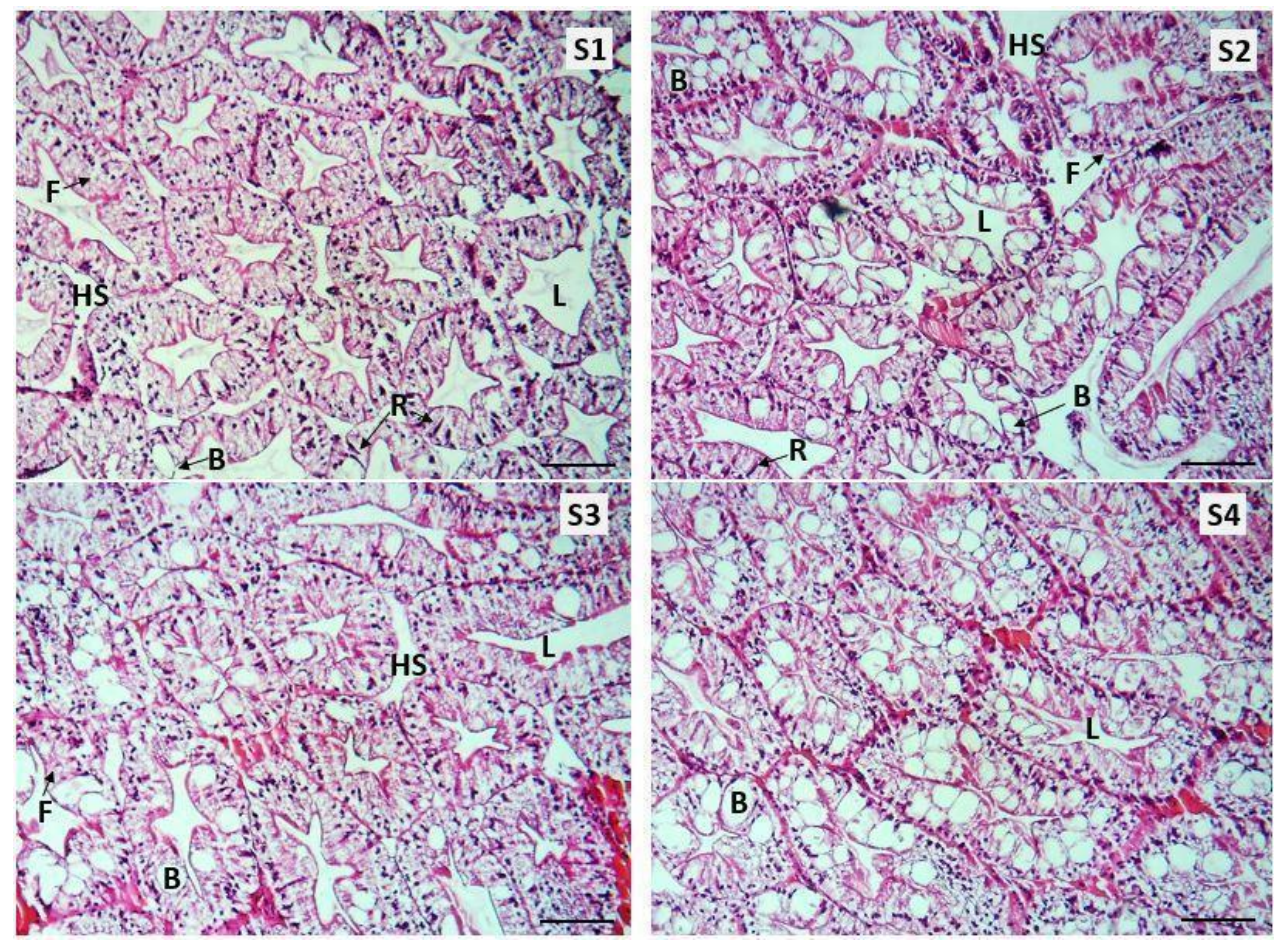

Figure 1. Hepatopancreas of A. leptodactylus by the groups in BFT culture conditions. B-cells: large vacuoles, R-cells: small vacuoles and F-cells: basophilic/nonvacuoles. H\&E, Bar $=50 \mu \mathrm{m}$. S1: 5 crayfish 0.24m ${ }^{-2}$. S2: 10 crayfish $0.24 \mathrm{~m}^{-2}$. S3: 15 crayfish $0.24 \mathrm{~m}^{-2}$. S4: 20 crayfish $0.24 \mathrm{~m}^{-2}$

\section{DISCUSSION}

The main advantage of BFT in aquaculture is to improve water quality by removing toxic nitrogenous compounds (Emerenciano et al., 2013). In the present study, water quality parameters such as water temperature, dissolved oxygen, and $\mathrm{pH}$ were within a normal range for narrow-clawed crayfish (Nedaei et al., 2019; Safari and Paolucci, 2017). Nitrite, nitrate, and phosphate levels were also in the appropriate range in crayfish culture for BFT conditions (Azhar et al., 2020). In the present study, BFT application with its unique water quality and nutritional characteristics reduced cannibalism rates by ensuring 24 hours instant diet to this decapod. In BFT conditions, narrow-clawed crayfish, which is naturally cannibalistic behavior, did not exhibit aggressive behavior.

Previous studies showed that narrow-clawed crayfish were affected by the increase in stocking density, and both survival rate and growth performance decreased in clear water conditions (Mazlum, 
2007; Farhadi and Jensen, 2016). Farhadi and Jensen (2016) expressed that 10 A. leptodactylus $\mathrm{m}^{-2}$ provided the best survival rate in the study where they tested three different stocking densities $(10,20$, and 40 individual $\mathrm{m}^{-2}$ ). Mazlum (2007) reported that the stocking density of $50 \mathrm{~A}$. leptodactylus $\mathrm{m}^{-2}$ ensured more yield. The main difference between Mazlum (2007) and Farhadi and Jensen (2016) trials was the initial live weights of crayfish (22.4 $\pm 0.5 \mathrm{mg}$ in Mazlum (2007), and 36.9-40.5 g in Farhadi and Jensen (2016). The initial weight variation can probably explain the optimum stocking rates. Our study demonstrated that BFT conditions had a positive effect on the overall survival rate of narrowclawed crayfish. By the stocking density groups, the survival rate was lower in the highest density group of narrow-clawed crayfish. It can be considered that as the decreased stocking density had a favorable effect on survival rate thus, the stocking densities of crayfish can be kept relatively low in BFT. The promising results of this study proved that BFT application can be an ambient habitat for narrow-clawed crayfish. The protein content of narrow-clawed crayfish tail meat in this study was similar to the values reported for red claw crayfish, Cherax quadricarinatus, reared in the earthen ponds (Thompson et al., 2005). Lipid content of tail meat of A. leptodactylus in BFT here was higher than that of C. quadricarinatus (Thompson et al., 2005) and A. leptodactylus fed on diets containing mannan oligosaccharide (Mazlum et al., 2010). This elevated amount of lipid content in tail meat may be attributable to BFT conditions.

Since no data on the culture of crayfish in the BFT are available in the literature, trials with other decapod crustaceans were taken into consideration to compare the results of our current research. Crustaceans have an only innate immune system and hemolymph parameters are important indicators in the evaluation of health conditions (Kaya et al., 2019). The role of BFT in improving hemolymph parameters and maintaining appropriate culture conditions in many crustaceans has been reported in previous studies (Xu and Pan, 2013; Li et al., 2019; Panigrahi et al., 2019; Kaya et al., 2020). In the current study, hemolymph indices and metabolites of narrow-clawed crayfish reflect the compatibility with the BFT conditions. The hemocyte number in the hemolymph of crustaceans is considered as the health indicator and stress biomarker (Jussila et al., 1998; Le Moullac and Haffner, 2000). To our knowledge there is no study on narrow-clawed crayfish with different stocking ratios in BFT, preventing us from the comparisons of the previous hemolymph indices. THCs in the hemolymph in the present study were not affected by the different stocking densities, showing the mean values between $47.93 \pm 15.49$ and $52.58 \pm 15.88\left(\times 10^{4}\right.$ cells $\left.\mathrm{mL}^{-1}\right)$. Hemolymph indices of this research showed a decreasing tendency by increasing crayfish density however, the decreases of THCs in higher stocking density groups were statistically insignificant. THCs were similar to the values reported for A. leptodactylus under normal conditions (Yildiz and Benli 2004). Contrarily, THCs counted in our study were lower than the THCs assessed in feeding experiments with A. leptodactylus fed with different ratios of fructo- and mannan oligosaccharides (Safari et al., 2014). The hyalinocyte ratio in our measurements was the most found hemocyte type in narrow-clawed crayfish in BFT. In the study of Sang et al. (2009) hyaline cells of marron, Cherax tenuimanus in control groups were of the highest ratio in all cell types, showing similarity with our findings in terms of sequencing the ratios of hemocyte types. The protein levels in hemolymph of crayfish, in general, have been reported to be between 20 to $75 \mathrm{mg} \mathrm{mL}^{-1}$ as a reference interval for healthy crayfish individuals (Sladkova and Kholodkevich, 2011). The hemolymph protein concentrations in all groups tested in the present study fell in the range of normal protein levels. Similar hemolymph protein concentrations $\left(24-25 \mathrm{~g} \mathrm{~L}^{-1}\right)$ were recorded for Cherax destructor individuals in normal conditions (Stara et al., 2018). The insignificant differences between groups show the normal physiological state of the crayfish in all groups. However, hemolymph protein of red swamp crayfish (Procambarus clarkii) was measured $61.61 \mathrm{mg} \mathrm{mL}^{-1}$ for normoxic conditions. (Bonvillain et al., 2012). Hemolymph protein concentrations in this study are below the values of healthy A. leptodactylus $\left(4.56 \mathrm{mg} \mathrm{dL}^{-1}\right)$ reported by Yildiz et al. (2005). This may be related to biotic and abiotic factors of BFT for crayfish thus, the physiological compensation mechanism associated with BFT conditions may result in alterations in hemolymph protein concentrations. Elevated hemolymph concentrations in crayfish can be an indication of stressful conditions (Yildiz and Benli, 2004). Glucose mobilization in crayfish has validity as a strong biomarker of the physiological status of the animal. In particular, higher levels of hemolymph glucose are linked to glycogenolysis hence, elevated hemolymph glucose concentrations are considered as acute biomarkers for stress. In our study, the glucose levels in hemolymph differed among the groups however, the changes in glucose levels were independent of the stocking density. In P. clarkii the 
hemolymph glucose was stated as $24 \mathrm{mg} / \mathrm{dL}$ for the normal physiological state of crayfish (Bonvillain et al., 2012) and $1.36 \mathrm{mmol} \mathrm{dL}^{-1}$ for Cherax destructor (Stara et al., 2018). Hemolymph glucose values below $10 \mathrm{mg} \mathrm{dL}^{-1}$ were reported in A. leptodactylus in normal conditions (Yildiz and Benli, 2004). Based on the literature cited, the hemolymph glucose values in our groups can be categorized as relatively high for all tested groups, corresponding to mild stress. It should be noted that elevated glucose levels are not the biomarker of chronic stress. Thus, the recovery from acute stress in culture conditions seems possible, demonstrating the need for more tests to measure the hemolymph glucose. Similar to hemolymph glucose, higher lactate levels in hemolymph are acute biomarkers of stress. Lactate is the end metabolic product of anaerobic metabolism in crustaceans and its level increases under stressful conditions to maintain homeostasis. In our study, the lactate levels in hemolymph did not show any significant differences among the groups. The lactate values measured here were higher than the lactate values in unstressed P. clarkii (Bonvillain et al., 2012) and hemolymph of Cherax destructor in the normal physiological state (Stara et al., 2018). Increases in hemolymph lactate levels of $P$. clarkii and Procambarus digueti in response to altered light intensity and durations were recorded by Fanjul-Moles et al. (1998). The increase in hemolymph lactate of $P$. digueti was 317 times the control values $\left(0.207 \mathrm{mmol} \mathrm{mL}^{-1}\right)$ after exposing crayfish to 1 week of LD 12:12, indicating extreme elevations of hemolymph lactate. The hemolymph lactate concentrations in this study are relatively higher however, the elevation in the lactate levels does not indicate higher levels of stress. Although both hemolymph glucose and lactate levels may represent mild stress response to BFT conditions in our study we did not observe any unhealthy individuals during the experiments. The elevations in these acute biomarkers (hemolymph glucose/lactate) may be linked to the exertion in the physiological response to adapt to the BFT.

It is known that the hepatopancreas with a tubular structure consisting of R-cells, B-cells, and Fcells is a highly vital organ in the decapods for digestion, absorption of nutrients, and the storage of lipids (Steinacker, 1981; Genc et al., 2007; Kaya et al., 2019a, 2019b). With these approaches, hepatopancreas histology can serve the general health status and metabolism of crayfish. Examined samples for all stocking groups in our study were found normal and healthy. The hepatopancreas histology results of this study were coherent with the other decapod species cultured in BFT (Furtado et al., 2015; Kaya et al., 2019a, 2019b, 2020).

\section{CONCLUSION}

BFT conditions for narrow-clawed crayfish raising may provide suitable conditions considering the growth performance, overall survival rates, and health status of the individuals. Stocking density in narrow-clawed crayfish culture should be kept relatively low to achieve higher survival rates under BFT conditions although the increased stocking density of narrow-clawed crayfish did not appear a potential risk factor for the physiological status of narrow-clawed crayfish as reflected in hemolymph indices associated with the metabolites and hepatopancreas histology.

\section{REFERENCES}

Anderson, M. B., Preslan, J.E., Jolibois, L., Bollinger, J.E., \& George, W.J, (1997). Bioaccumulation of lead nitrate in red swamp crayfish (Procambarus clarkii). Journal of Hazardous Materials, 54(1-2), 15-29. https//doi.org/10.1016/S0304-3894(96)01852-3

AOAC. (1997). Official methods of analysis of AOAC international, (Cunniff PA ed.) 16th edn. Association of Official Analytical Communities International, Arlington, VA, USA.

APHA. (1998). Standard methods for the examination of water and wastewater, 20th edn. American Public Health Association, New York.

Avnimelech, Y. (2012). Biofloc technology - a practical guidebook, 2nd edn. The World Aquaculture Society, Baton Rouge

Azhar, M. H., Suciyono, S., Budi, D. S., Ulkhaq, M. F., Anugrahwati, M., \& Ekasari, J. (2020). Biofloc-based co-culture systems of Nile tilapia (Oreochromis niloticus) and red claw crayfish (Cherax quadricarinatus) with different carbon-nitrogen ratios. Aquaculture International, 1-12. https,//doi.org/10.1007/s10499-020-00526-z

Bancroft, J. D, \& Stevens, A. (1977). Theory and practice of histological techniques, Churchill Livingstone, London

Bligh, E. G, \& Dyer, W. J. (1959). A rapid method of total lipid extraction and purification. Canadian Journal Biochemichal Physiolology, 37, 911-917. 
Bonvillain, C. P., Rutherford, D. A., Kelso, W. E., \& Green, C. C. (2012). Physiological biomarkers of hypoxic stress in red swamp crayfish Procambarus clarkii from field and laboratory experiments. Comparative Biochemistry and Physiology Part A: Molecular \& Integrative Physiology, 163(1), 15-21. https://doi.org/10.1016/j.cbpa.2012.04.015

Emerenciano, M., Cuzon, G., Paredes, A., \& Gaxiola, G. (2013). Evaluation of biofloc technology in pink shrimp Farfantepenaeus duorarum culture: growth performance, water quality, microorganisms' profile and proximate analysis of biofloc. Aquaculture international, 21(6), 1381-1394.

Fanjul-Moles, M. L., Bosques-Tistler, T., Prieto-Sagredo, J., Castanón-Cervantes, O., \& Fernández-Rivera-R1o, L. (1998). Effect of variation in photoperiod and light intensity on oxygen consumption, lactate concentration and behavior in crayfish Procambarus clarkii and Procambarus digueti. Comparative Biochemistry and Physiology Part A: Molecular \& Integrative Physiology, 119(1), 263-269. https://doi.org/10.1016/S1095-6433(97)00413-3

FAO. (2018). The State of World Fisheries and Aquaculture 2018- Meeting the sustainable development goals. Contributing to food security and nutrition for all. Food and Agriculture Organization of the United Nations, Rome.

Farhadi, A., \& Jensen, M. A. (2016) Effects of photoperiod and stocking density on survival, growth, and physiological responses of narrow-clawed crayfish (Astacus leptodactylus). Aquaculture Research, 47(8), 2518-2527. https://doi.org/10.1111/are.12700

Fóes, G. K., Fróes, C., Krummenauer, D., Poersch, L., \& Wasielesky, W. (2011). Nursery of pink shrimp Farfantepenaeus paulensis in biofloc technology culture system: survival and growth at different stocking densities. Journal of Shellfish Research, 30(2), 367-373. https://doi.org/10.2983/035.030.0224

Furtado, P. S., Campos, B. R., Serra, F. P., Klosterhoff, M., Romano, L. A., \& Wasielesky, W. (2015). Effects of nitrate toxicity in the Pacific white shrimp, Litopenaeus vannamei, reared with biofloc technology (BFT). Aquaculture international, 23(1):315-327.

Gargioni, R., \& Barracco, M. A. (1998). Hemocytes of the palaemonids Macrobrachium rosenbergii and M. acanthurus, and of the Penaeid Penaeus paulensis. Journal of Morphology, 236(3), 209-221. https://doi.org/10.1002/(SICI)1097-4687(199806)236:3\%3C209::AID-JMOR4\%3E3.0.CO;2-Y

Genc, M. A., Aktas, M., Genc, E., \& Yilmaz, E. (2007). Effects of dietary mannan oligosaccharide on growth, body composition and hepatopancreas histology of Penaeus semisulcatus (de Haan 1844). Aquaculture Nutrition, 13(2), 156-161. https://doi.org/10.1111/j.1365-2095.2007.00469.x

Genç, E., Kaya, D., Dinçer, S., Genç, M. A., \& Aktaş, M. (2019). Biofloc application in narrow-clawed crayfish (Astacus leptodactylus) culture: Preliminary results. Sözlü Sunum, 3rd International Congress on Advances in Bioscience and Biotechnology (ICABB), 10-14 july 2019. (pp: 71-78) https://www.icabb.eu/sites/default/files/icabb_2019_proceedings.pdf

Harlıoğlu, M. M., \& Farhadi, A. (2017). Factors affecting the reproductive efficiency in crayfish: implications for aquaculture. Aquaculture Research, 48(5), 1983-1997. https://doi.org/10.1111/are.13263

Hauton, C. (2012). The scope of the crustacean immune system for disease control. Journal of invertebrate pathology, 110(2), 251-260. https://doi.org/10.1016/j.jip.2012.03.005

Johnson, P. T. (1980). Histology of the blue crab Callinectes sapidus A model for the Decapoda. Praeger Publishers. New York

Jussila, J., Jago, J., Tsvetnenko, E., Dunstan, B., Evans, L. H. (1997). Total and differential haemocyte counts in western rock lobsters (Panulirus cygnus George) under post-harvest stress. Marine and Freshwater Research, 48(8), 863-868. https://doi.org/10.1071/MF97216

Kaya, D., Genc, E., Genc, M. A., Aktas, M., Eroldogan, O. T, \& Guroy, D. (2020). Biofloc technology in recirculating aquaculture system as a culture model for green tiger shrimp, Penaeus semisulcatus: Effects of different feeding rates and stocking densities. Aquaculture, 735526. https://doi.org/10.1016/j.aquaculture.2020.735526

Kaya, D., Genc, M. A., Aktas, M., Yavuzcan, H., Ozmen, O., \& Genc, E. (2019). Effect of biofloc technology on growth of speckled shrimp, Metapenaeus monoceros (Fabricus) in different feeding regimes. Aquaculture Research, 50(10), 2760-2768. https://doi.org/10.1111/are.14228

Yildiz, H. Y., Köksal, G., \& Benli, A. C. K. (2004). Physiological response of the crayfish, Astacus leptodactylus to saline $\quad$ water. Crustaceana, 77(10), $1271-1276$. https://doi.org/10.1163/1568540043166056

LeMoullac, G., Haffner, P. (2000). Environmental factors affecting immune responses in Crustacea. Aquaculture, 191(1-3), 121-131. https://doi.org/10.1016/S0044-8486(00)00422-1

Li, J., Li, J., Li, W., Sun, Y., Liu, X., Liu, M., \& Cheng, Y. (2019). Juvenile Procambarus clarkii farmed using biofloc technology or commercial feed in zero water exchange indoor tanks: A comparison of growth performance, enzyme activity and proximate composition. Aquaculture Research, 50(7), 1834-1843. https://doi.org/10.1111/are.14065 
Lin, X., \& Söderhäll, I. (2011). Crustacean hematopoiesis and the astakine cytokines. Blood, The Journal of the American Society of Hematology, 117(24), 6417-6424. https://doi.org/10.1182/blood-2010-11-320614

Liu, G., Zhu, S., Liu, D., Guo, X., \& Ye, Z. (2017). Effects of stocking density of the white shrimp Litopenaeus vannamei (Boone) on immunities, antioxidant status, and resistance against Vibrio harveyi in a biofloc system. Fish \& Shellfish Immunology, 67, 19-26. https://doi.org/10.1016/j.fsi.2017.05.038

Mazlum, Y. (2007). Stocking density affects the growth, survival, and cheliped injuries of third instars of narrow-clawed crayfish, Astacus leptodactylus Eschscholtz, 1823 juveniles. Crustaceana, 803-815. https://doi.org/10.1163/156854007781363114

Minaz, M., \& Kubilay, A. (2021). Operating parameters affecting biofloc technology: carbon source, carbon/nitrogen ratio, feeding regime, stocking density, salinity, aeration, and microbial community manipulation. Aquaculture International, 1-20.

Nedaei, S., Noori, A., Valipour, A., Khanipour, A. A., \& Hoseinifar, S. H. (2019). Effects of dietary galactooligosaccharide enriched commercial prebiotic on growth performance, innate immune response, stress resistance, intestinal microbiota, and digestive enzyme activity in Narrow-clawed crayfish (Astacus $\begin{array}{lllll}\text { leptodactylus } \quad \text { Eschscholtz, } & \text { 1823). } & \text { 8quaculture, } & \text { 499, }\end{array}$ https://doi.org/10.1016/j.aquaculture.2018.08.076

Negrini, C., Castro, C. S. D., Bittencourt-Guimarães, A. T., Frozza, A., Ortiz-Kracizy, R., \& Cupertino-Ballester, E. L. (2017). Stocking density for freshwater prawn Macrobrachium rosenbergii (Decapoda, Palaemonidae) in biofloc system. Latin American Journal of Aquatic Research, 45(5), 891-899. http://dx.doi.org/10.3856/vol45-issue5-fulltext-3

Panigrahi, A., Sundaram, M., Saranya, C., Swain, S., Dash, R. R., \& Dayal, J. S. (2019). Carbohydrate sources deferentially influence growth performances, microbial dynamics, and immunomodulation in Pacific white shrimp (Litopenaeus vannamei) under biofloc system. Fish \& Shellfish Immunology, 86, 12071216. https://doi.org/10.1016/j.fsi.2018.12.040

Persson, M., Cerenius, L., \& Söderhäll, K. (1987). The influence of haemocyte number on the resistance in the freshwater crayfish Pacifastacus leniusculus to the parasitic fungus Aphanomyces astaci. Journal of Fish Diseases, 10, 471-477. https://doi.org/10.1111/j.1365-2761.1987.tb01098.x

Safari, O., \& Paolucci, M. (2017). Modulation of growth performance, immunity, and disease resistance in narrow-clawed crayfish, Astacus leptodactylus leptodactylus (Eschscholtz, 1823) upon synbiotic feeding. Aquaculture, 479:333-341. https://doi.org/10.1016/j.aquaculture.2017.05.049

Safari, O., Shahsavani, D., Paolucci, M., \& Atash, M. M. S. (2014). Single or combined effects of fructo-and mannan oligosaccharide supplements on the growth performance, nutrient digestibility, immune responses, and stress resistance of juvenile narrow-clawed crayfish, Astacus leptodactylus leptodactylus Eschscholtz, 1823. Aquaculture, 432:192-203. https://doi.org/10.1016/j.aquaculture.2014.05.012

Sang, H. M., \& Fotedar, R. (2009). Dietary supplementation of mannan oligosaccharide improves the immune responses and survival of marron, Cherax tenuimanus (Smith, 1912) when challenged with different stressors. Fish \& Shellfish Immunology, 27(2), 341-348. https://doi.org/10.1016/j.fsi.2009.06.003

Sladkova, S. V., \& Kholodkevich, S. V. (2011). Total protein in hemolymph of crawfish Pontastacus leptodactylus as a parameter of the functional state of animals and a biomarker of quality of habitat. Journal of Evolutionary Biochemistry and Physiology, 47(2), 160-167.

Söderhäll, K., Cerenius, L. (1998). Role of the prophenoloxidase-activating system in invertebrate immunity. Current Opinion in Immunology, 10(1), 23-28. https://doi.org/10.1016/S0952-7915(98)800265

Stara, A., Kouba, A., \& Velisek, J. (2018). Biochemical and histological effects of sub-chronic exposure to atrazine in crayfish Cherax destructor. Chemico-Biological Interactions, 291, 95-102. https://doi.org/10.1016/j.cbi.2018.06.012

Steinacker, A. (1981). Histology of the Blue Crab, Callinectes sapidus A Model for the Decapoda. Phyllis J. Johnson. Q Rev Biol

Thompson, K. R., Muzinic., L. A., Engler, L. S., \& Webster, C. D. (2005). Evaluation of practical diets containing different protein levels, with or without fish meal, for juvenile Australian red claw crayfish (Cherax quadricarinatus). Aquaculture, 244(1-4), https://doi.org/10.1016/j.aquaculture.2004.11.018

Ulikowski, D., \& Krzywosz, T. (2004). The impact of photoperiod and stocking density on the growth and survival of narrow-clawed crayfish (Astacus leptodactylus Esch.) larvae. Fisheries \& Aquatic Life, 12(1), 81-86.

Vogt, G. (2019). Functional cytology of the hepatopancreas of decapod crustaceans. Journal of morphology, 280(9), 1405-1444. https://doi.org/10.1002/jmor.21040

Winzer, A. (2005). Hemocytological and physiological analyses of juvenile $(0+)$ semi-intensively cultured, wildstock, and farmed marron, Cherax tenuimanus. Journal of Applied Aquaculture, 17(1), 1-18. https://doi.org/10.1300/J028v17n01_01 
Xu, W. J., \& Pan, L. Q. (2013). Enhancement of immune response and antioxidant status of Litopenaeus vannamei juvenile in biofloc-based culture tanks manipulating high $\mathrm{C} / \mathrm{N}$ ratio of feed input. Aquaculture, 412, 117-124. https://doi.org/10.1016/j.aquaculture.2013.07.017

Yildiz, H. Y., \& Benli, A. C. K. (2004). Nitrite toxicity to crayfish, Astacus leptodactylus, the effects of sublethal nitrite exposure on hemolymph nitrite, total hemocyte counts, and hemolymph glucose. Ecotoxicology and Environmental Safety, 59(3), 370-375. https://doi.org/10.1016/j.ecoenv.2003.07.007

Yu, J., Xiong, M., Ye, S., Li, W., Xiong, F., Liu, J., \& Zhang, T. (2020). Effects of stocking density and artificial macrophyte shelter on survival, growth and molting of juvenile red swamp crayfish (Procambarus clarkii) under experimental conditions. Aquaculture, 521, 735001. https://doi.org/10.1016/j.aquaculture.2020.735001 